\title{
EU-Citizens Should Have the Right to Vote in National Elections
}

\author{
Philippe Cayla and Catriona Seth
}

Imagine being a law-abiding EU citizen, living in the EU, and having no right to vote for the government whose decisions will impact on your daily life. Does this sound like an Orwellian nightmare? Think again. It is the fate of large numbers of your neighbours or friends. Let us take the case of Alex, a British journalist living in France. He can vote for the local mayor in Paris and for members of the European parliament. He cannot, however, elect the president of France whose policies could influence his tax situation or decide whether a high-speed train station is located in his town. In the same way, Kirsten, who is a Danish teacher residing in Spain has no say in the election of a government whose decisions will impact on her retirement pension and on the educational system in which she works. Surely this is regrettable, to say the least. Should being European in Europe not entitle you to have a say in the way the part of Europe in which you live, work and pay taxes is governed? EU nationals have the right to vote in European and local elections, wherever they live within the EU. Should they not also be entitled to vote in national elections even if they reside in an EU nation other than their home country? Should their lack of a possibility to use the democratic process in order to influence policies by which they will be directly affected not be construed as a potential obstruction to mobility? Who wants to go and live in a country without being able to exercise full democratic rights? Surely it is time for the EU to extend EU citizens' voting rights to national elections: this form of residential right would help integration, encourage mobility and enhance the value of EU citizenship. We feel a European Citizens' Initiative might be a way to achieve this. 
Go to the Letmevote website (www.letmevote.eu) and to the official description of the 'Let me vote' ECI on the European Commission website.

Read the article by Philippe Cayla in Libération 8 December $2011^{1}$ and his article written with Catherine Colonna in Le Monde 3 April $2012^{2}$.

1 Cayla, P. (2012), 'Commençons par les Européens' [Let's start with the Europeans] Libération, 08/12/2011, available at http://www.liberation.fr/ societe/2011/12/08/commencons-par-les-europeens_780280

2 Cayla, P. \& C. Colonna (2012), 'Accordons le droit de vote aux Européens!' [Let's give Europeans the right to vote!] Le Monde, 02/04/2012, available at http://www.lemonde.fr/idees/article/2012/04/02/accordons-le-droit-de-voteaux-europeens 1679092 3232.html\#x0uiOs 1t0X1Q03E7.99

Open Access This chapter is licensed under the terms of the Creative Commons Attribution 4.0 International License (http://creativecommons.org/licenses/by/4.0/), which permits use, sharing, adaptation, distribution and reproduction in any medium or format, as long as you give appropriate credit to the original author(s) and the source, provide a link to the Creative Commons license and indicate if changes were made.

The images or other third party material in this chapter are included in the chapter's Creative Commons license, unless indicated otherwise in a credit line to the material. If material is not included in the chapter's Creative Commons license and your intended use is not permitted by statutory regulation or exceeds the permitted use, you will need to obtain permission directly from the copyright holder. 